Maciejewska-Mieszkowska K., Legal and financial considerations of national and ethnic minorities' broadcasts in the public regional media, „Economics and Law”, Polszakiewicz B., Boehlke J. (ed.), Vol. 13, No. 1/2014, pp. 83-94. DOI: http://dx.doi.org/10.12775/EiP.2014.007.

\title{
LEGAL AND FINANCIAL CONSIDERATIONS OF NATIONAL AND ETHNIC MINORITIES' BROADCASTS IN THE PUBLIC REGIONAL MEDIA
}

\section{SUMMARY}

One of the fundamental duties of public media in Poland is to implement the so-called social mission, within which the media are obliged, among other things, to broadcast programs for national and ethnic minorities. The basis for undertaking by minorities any activities in broadcasting are legal and financial considerations, which are the main determinants of creating the programs and their broadcasting.

In order to determine the legal conditions which guarantee broadcasting for minorities and in order to compare the number of broadcasts and related costs, the national law and documents of the National Broadcasting Council (KRRiT) were subjected to research analysis. In the analysis the following methods were applied: descriptive, comparative and statistical. They allowed to confirm the research hypothesis which assumes that the Polish state creates appropriate conditions for broadcasting for minorities, thanks to provisions of the law and funds transferred from subscriptions. However, equally important determinant in this field is the initiative and activity of the minority communities themselves, since according to KRRiT they are supposed to realize and run broadcasts for minorities.

Keywords: regional broadcasting, regional broadcast center

JEL Classification: Z18, H5

" Katarzyna Maciejewska-Mieszkowska, University of Warmia and Mazury in Olsztyn, Facoulty of Social Sciences, Institute of Political Science, ul. ks. Feliksa Szrajbera 11, 10-007 Olsztyn, phone: +48 8952708 01, e-mail: kasiabc@poczta.onet.pl. 


\section{INTRODUCTION}

According to the National Census of Population and Housing of 2011, the territory of Poland is inhabited by about 871 thous. people (2.26\%) declaring both Polish and other than Polish national and ethnic identity. 597 thous. (1,55\%) confirmed their national and ethnic identities as exclusively non-Polish, including 46 thous. respondents who declared two nonPolish identities ${ }^{1}$. At the same time it should be noted that the census considered all the nationalities and ethnic identities declared by the respondents.

However, the Act on National and Ethnic Minorities and Regional Language of $6^{\text {th }}$ Jan. 2005 lists only nine national minorities (Belarusian, Czech, Lithuanian, German, Armenian, Russian, Slovak, Ukrainian and Jewish) and four ethnic (Karaim, Lemko, Romani and Tatar), because the legislator assumed that the national and ethnic minority is a group of Polish citizens that fulfills all the following conditions:

1. it is smaller in number than the rest of the population of the Republic of Poland;

2. it is essentially distinguished from the rest of the citizens by its own language, culture or tradition;

3. it is guided by the will to safeguard its language, culture or tradition;

4. it is conscious of its individual historical national (ethnic KM-M) community and is interested in its expression and protection;

5. its ancestors have resided within the present territory of the Republic of Poland for at least a hundred years.

According to the Act the only difference between the national and ethnic minorities is the fact that the first one 'identifies itself with the nation organized in its own country', while the other does not. The difference is a necessary condition for acknowledging a particular community as one of minorities (Art. 2.1).

The above Act not only clarified the concept of the national and ethnic minorities and stated their rights, privileges and responsibilities, but also introduced additional statements to the following acts:

- the Education System Act of 7th Sept. 1991;

- the Broadcasting Act of 29th Dec. 1992;

${ }_{1}$ GUS, Przynależność narodowo-etniczna ludności - wyniki spisu ludności i mieszkań 2011, http://www.stat.gov.pl/cps/rde/xbcr/gus/Przynaleznosc_narodowo-etniczna_w_2011_NSP.pdf (30.05.2013). 
- the Government Administration Sectors Act of 4th Sept. 1997;

- the Polish Language Act of 7th Oct. 1999;

- the Act on Official Names of Localities and Physiographic Objects of 29th Aug. 2003.

\section{LAW REGULATIONS}

In the case of amendments to the Broadcasting Act of 29th Dec. 1992, it is Art. 21, section 1a, point $8 \mathrm{a}$ which deserves a special attention, addition of which caused that one of the tasks of public media within implementation of social mission is nowadays, among other things, 'broadcasting news programs in the languages of national and ethnic minorities and in regional languages ${ }^{2}$.

It should be noted at the same time that in 2010 the National Broadcasting Council (KRRiT), in order to determine 'which of the broadcasts adequately address the needs of national and ethnic minorities' ${ }^{3}$ clarified what conditions must be fullfilled by the broadcasts aimed at this group of audience. According to KRRiT the broadcasts are:

- entirely devoted to (...) issues concerning national and ethnic minorities or to communities using regional languages;

- the representatives of national or ethnic minorities or of communities using regional languages, not only appear in programs, but also talk about themselves or their issues;

- the target audience is a particular national or ethnic minority or a community using a regional language;

- they are realized in a language of national or ethnic minority or in a regional language;

- they are edited by the staff consisting of the representatives of a particular national or ethnic minority or a community using a regional language't.

A broadcast must comply with all the above characteristics.

2 Ustawa z dnia 29 grudnia 1992 r. o radiofonii i telewizji z późniejszymi zmianami, Dz.U. 1993, nr 7, poz. 34, Dz.U. 1995, nr 66, poz. 335 i Dz.U. 1995, nr 142, poz. 701, art. 22 ust. 2, art. 23 ust. 1.

${ }^{3}$ KRRiT, Stanowisko Krajowej Rady Radiofonii i Telewizji w sprawie audycji dla mniejszości narodowych $i$ etnicznych oraz spoteczności postugującej się jezykiem polskim w publicznej radiofonii i telewizji, http://www.krrit.gov.p1/Data/Files/_public/Portals/0/stanowiska/st2010/st_101027_ mniejszosci.pdf (30.05.2013).

${ }^{4}$ Ibidem. 
The second amendment to the Act (Art.30, section 4a) concerns the make-up of program councils. It states that 'When appointing program councils of branches broadcasting program services in the languages of national and ethnic minorities and in regional languages, branch directors shall take into account candidates put forward by social organizations of national and ethnic minorities and communities using regional languages.'5 A very important record in the context of broadcasts for minorities is Art.13, section 1, which gives broadcasters a right to determine the content of the program services independently.

Public media, while realizing broadcasts for minorities, must comply with the provisions of the European Charter for Regional or Minority Languages, which have been binding for the Republic of Poland since $1^{\text {st }}$ June 2009 and with the Council of Europe's Framework Convention for the Protection of National Minorities drawn up in Strasburg on $1^{\text {st }}$ Feb. 1995.

These regulations apply to both nationwide and regional media. However, it should be noted that the vast majority of program services for minorities in the meaning proposed by KRRiT are broadcast within regional bandwidth, which results mainly from the dispersion of individual communities in the territory of Poland. The nationwide media mainly present programs aimed at the general public and they are universal, showing chiefly the culture and traditions of particular minorities (e.g. the Festival of Jewish Culture). Another characteristic formula of programs about minorities which appears in the nationwide media are journalistic reports, which most often are referred to as programs on current affairs and news and relate to events such as, for example, Orthodox Christmas holidays or the Festival of Ukrainian Culture ${ }^{6}$.

\section{POLISH REGIONAL RADIO BROADCASTERS}

According to the data provided by KRRiT in the years 2008-2011, twelve public regional and urban radio stations broadcast programs for minorities, and both the number of hours of broadcasts and their continuity changed over particular years, which is presented in table 1 .

5 Ustawa z dnia 29 grudnia 1992 r..., op. cit.

${ }^{6}$ Based on information presented by Marzena Giedrojć in the paper titled 'The issue of mass media and the access of national and ethnic minorities to them in the work of the National and Ethnic Minorities Committee of the Sejm RP', during the III International Scientific Conference on the topic 'National and ethnic minorities in Poland on the European background. Media of minorities, minorities in media', which was held in Lublin on 11-13 June 2013. 
Table 1. Information on the number of realized hours of broadcasts for national and ethnic minorities and communities using regional languages in the Regional Centres of the Polish Radio in the years 2008-2011

\begin{tabular}{|c|c|c|c|c|}
\hline PUBLIC BrOADCASTING COMPANIES & $\begin{array}{c}\text { NUMBER OF } \\
\text { HOURS } \\
\text { YEAR 2008 }\end{array}$ & $\begin{array}{c}\text { NUMBER OF } \\
\text { HOURS } \\
\text { YEAR 2009 }\end{array}$ & $\begin{array}{c}\text { NUMBER OF } \\
\text { HOURS } \\
\text { YEAR 2010 }\end{array}$ & $\begin{array}{c}\text { NUMBER OF } \\
\text { HOURS } \\
\text { YEAR 2011 }\end{array}$ \\
\hline 1. Radio Białystok S.A. & 286 & 286 & 260 & 286 \\
\hline 2. Radio Gdańsk S.A. & 119 & 105 & 92 & 99 \\
\hline 3. Radio Katowice S.A. & 23 & 17,9 & 35,8 & 82 \\
\hline 4. Radio Koszalin S.A. & 76,3 & 82 & 78,1 & 82 \\
\hline 5. Radio Kraków S.A. & 15 & 17 & 26 & 32 \\
\hline 6. Radio Lublin S.A. & 0 & 0,5 & 0 & 0 \\
\hline 7. Radio Olsztyn S.A. & 48 & 178,5 & 186,5 & 48 \\
\hline 8. Radio Opole PRO FM S.A. & 118 & 159 & 113 & 131 \\
\hline 9. Radio Rzeszów S.A. & 139 & 141 & 147 & 148 \\
\hline 10. Radio Szczecin S.A. & 2 & 2 & 61 & 14 \\
\hline 11. Warszawa Radio dla Ciebie S.A. & $1112^{*}$ & $619^{*}$ & 0 & 0 \\
\hline 12. Radio Wroclaw S.A. & 10 & 10 & 10 & 5 \\
\hline Total: & 1948,3 & 1617,9 & 1009,4 & 927 \\
\hline
\end{tabular}

* Broadcasts created in co-operation with the European Radio for Belarus (from the transmitter in Łosice).

Source: KRRiT, Realizacja misji mediów publicznych w zakresie nadawania audycji dla mniejszości narodowych i etnicznych oraz społeczności posługującej się językiem regionalnym, http://www.krrit.gov.pl/Data/Files/_public/Portals/0/konferencje/mniejszosci_maj_2012/prezentacja_spotkanie_31-05-2012.pdf (30.05.2013).

In the year 2012 the number of radio stations broadcasting for minorities decreased to ten and they were only regional stations (figure 1.). The leader in respect of the broadcasting time and diversity of the programs was undoubtedly the Polish Radio Białystok, because materials prepared by the station were broadcast in the following languages: Russian, Belarusian, Lithuanian and Ukrainian. Among the recipients of the broadcasts for minorities were also groups of Roms and Tatars of Podlasie region ${ }^{7}$. Such a wide range of programs in the case of the station is mainly due to two factors. The media region, which is covered by the Polish Radio Białystok, is inhabited by a community which is very diverse in terms of ethnicity or nationality. Secondly, these communities are characterized by a high social activity, example of which is initiating and realization of radio broadcasts by representatives of the communities.

7 KRRiT, Media Publiczne 2012. Aneks do sprawozdania, p. 42, http://www.krrit.gov.pl/Data/ Files/_public/Portals/0/sprawozdania/spr2013/aneks_2013.pdf (30.05.2013). 


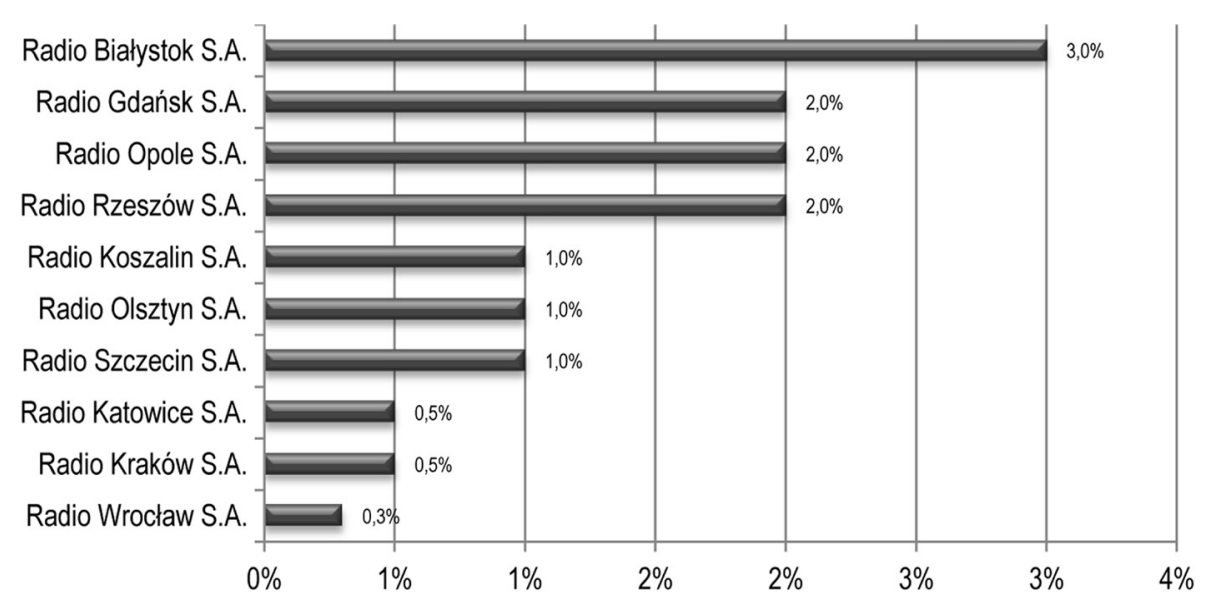

Figure 1. The share of programs in regional languages for national and ethnic minorities in public regional and urban stations

Source: the author's elaboration on the basis of the data contained in KRRiT, Media Publiczne 2012. Aneks do sprawozdania, http://www.krrit.gov.pl/Data/Files/_public/Portals/0/sprawozdania/spr2013/aneks_2013.pdf (30.05.2013).

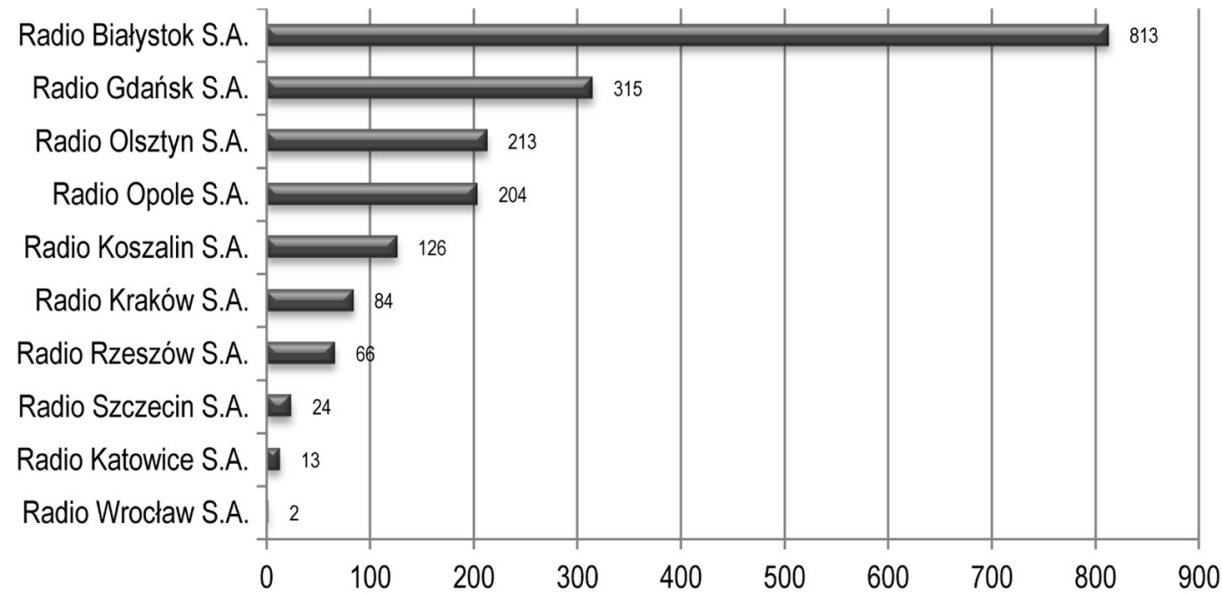

Figure 2. Expenses incurred on broadcasts in regional languges for national and ethnic minorities, financed with subscriptions, in thousands of PLN

Source: the author's elaboration on the basis of the data contained in KRRiT, Media Publiczne 2012..., op. cit.

Public regional radio stations are mainly supported with funds generated from subscriptions and advertising. According to the data of KRRiT, in the case of regional radio stations, funds obtained from subscriptions comprise from $70 \%$ to $100 \%$ of their budget. At the same time it should be noted 
that the annual cost of undistorted work of a public regional station is more than 10 million PLN $^{8}$. Therefore, their missionary activity is financed primarily by the subscriptions. In the year 2012 the stations obtained for their activity 148,8 million PLN in total ${ }^{9}$, including ten (out of seventeen stations) which obtained 1,860 million PLN for transmission and realization of broadcasts for minorities. Distribution of the funds among individual broadcasters is presented in figure 2 .

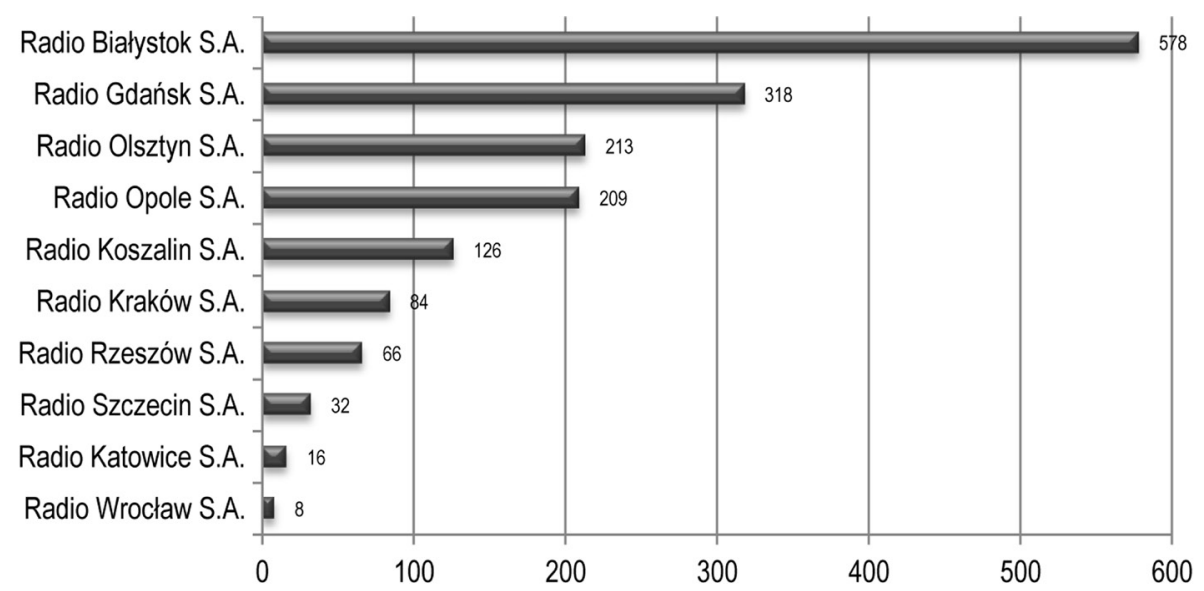

Figure 3. Costs of missionary activity incurred on broadcasts for national and ethnic minorities and broadcasts in regional languages, in thousands PLN

Source: the author's elaboration on the basis of the data contained in KRRiT, Media Publiczne 2012..., op. cit.

Figure 3 presents costs related to broadcasting programs for minorities by regional stations in the year 2012. At the same time it should be noted that the document by KRRiT titled 'Public media 2012. Annex to the report' mentions, in the case the Radio Olsztyn, two sums as part of the costs incurred: 49 thous. PLN on broadcasts for national and ethnic minorities and in regioanl languages, and 164 thous. PLN on creation and broadcasting a program for the Ukrainian minority ${ }^{10}$. The distribution is due to the so-called radio signal split, which means broadcasting for the Ukrainian minority in

${ }^{8} \mathrm{KRRiT}$, Informacja o podstawowych problemach radiofonii i telewizji w 2012 roku, p. 77, http://www.krrit.gov.pl/Data/Files/_public/Portals/0/sprawozdania/spr2013/informacja_ krrit_2013.pdf (30.05.2013).

9 PAP, Rośnie ściagalność abonamentu. Zastuga Poczty?, http://www.polskieradio.pl/5/3/ Artykul/751958,Rosnie-sciagalnosc-abonamentu-Zasluga-Poczty (30.05.2013).

${ }^{10}$ KRRiT, Media Publiczne 2012..., op. cit., p. 93. 
two radio frequencies: $99,6 \mathrm{MHz}$ and 103,2 MHz. The first frequency allows broadcasting via a local bandwidth from the transmitter in Miłki, while the other via a regional bandwidth from three transmitters in: Olsztyn, Miłki near Giżycko and Jagodnik near Elbląg. Programs broadcast via a local bandwidth reach only those listeners who live in the north of the Warmian-Masurian voivodeship. However, they do not reach Olsztyn, Elblag and the south-east part of the voivodeship ${ }^{11}$.

\section{REGIONAL BRANCHES OF PUBLIC TELEVISION}

In the years 2008-2011 all regional branches of Polish Television S.A. broadcast programs for national and ethnic minorities and as in the case of radio stations, the leader in respect of the broadcasting time was the television branch in Białystok. It also should be noted that the total number of hours of materials broadcast by all the branches gradually increased from 179,6 hours in the year 2008 to 270,4 hours in the year 2011. Their fluctuation, in the case of each of the branches, is presented in table 2 .

Table 2. The share of programs in national, ethnic and regional languages broadcast by regional branches of the Polish Television S.A. in the years 2008-2011

\begin{tabular}{|c|c|c|c|c|}
\hline $\begin{array}{c}\text { POLISH TELEVISION S.A. } \\
\text { - LOCAL BRANCHES }\end{array}$ & $\begin{array}{c}\text { NUMBER OF HOURS } \\
\text { YEAR } 2008\end{array}$ & $\begin{array}{l}\text { NUMBER OF HOURS } \\
\text { YEAR } 2009\end{array}$ & $\begin{array}{l}\text { NUMBER OF HOURS } \\
\text { YEAR } 2010\end{array}$ & $\begin{array}{c}\text { NUMBER OF HOURS } \\
\text { YEAR } 2011\end{array}$ \\
\hline 1. Białystok & 37 & 55,2 & 70,7 & 71,9 \\
\hline 2. Bydgoszcz & 4,2 & 6,2 & 8 & 9,1 \\
\hline 3. Gdańsk & 37,6 & 39,3 & 28,6 & 23,5 \\
\hline 4. Gorzów Wielkopolski & 4,2 & 6,2 & 8 & 10,2 \\
\hline 5. Katowice & 14,2 & 16,3 & 14,4 & 16,8 \\
\hline 6. Kielce & 4,2 & 6,2 & 8 & 9,1 \\
\hline 7. Kraków & 7,4 & 9 & 8 & 9,1 \\
\hline 8. Lublin & 4,2 & 6,2 & 8 & 9,1 \\
\hline 9. Łódź & 4,2 & 6,2 & 8 & 9,1 \\
\hline 10. Olsztyn & 17,7 & 17,6 & 16,6 & 24 \\
\hline 11. Opole & 23,4 & 33,2 & 31,2 & 32,7 \\
\hline 12. Poznań & 4,2 & 6,2 & 8 & 9,1 \\
\hline 13. Rzeszów & 4,5 & 6,9 & 8 & 9,4 \\
\hline 14. Szczecin & 4,2 & 6,2 & 8 & 9,1 \\
\hline 15. Warszawa & 4,2 & 6,2 & 8 & 9,1 \\
\hline
\end{tabular}

11 According to information obtained from PR Olsztyn. 


\begin{tabular}{|c|c|c|c|c|}
\hline $\begin{array}{c}\text { POLISH TELEVISION S.A. } \\
\text { - LOCAL BRANCHES }\end{array}$ & $\begin{array}{c}\text { NUMBER OF HOURS } \\
\text { YEAR 2008 }\end{array}$ & $\begin{array}{c}\text { NUMBER OF HOURS } \\
\text { YEAR 2009 }\end{array}$ & $\begin{array}{c}\text { NUMBER OF HOURS } \\
\text { YEAR 2010 }\end{array}$ & $\begin{array}{c}\text { NUMBER OF HOURS } \\
\text { YEAR } 2011\end{array}$ \\
\hline 16. Wroclaw & 4,2 & 6,2 & 8 & 9,1 \\
\hline Total: & 179,6 & 233,3 & 249,5 & 270,4 \\
\hline
\end{tabular}

Source: KRRiT, Realizacja misji..., op. cit.

According to the data presented by KRRiT, in the year 2012 the number of regional centers broadcasting for minorities dropped from sixteen to eight compared to previous years (figure 4). In addition, 'compared to 2011 the part of such broadcasts was increased by the branches in Kielce and Szczecin. In other branches there was reported a slight decrease in annual time spent on such broadcasts ${ }^{12}$. The most diverse offer was presented by the regional center in Białystok, which broadcast materials in the following languages: Ukrainian, Russian, Belarusian and Lithuanian.

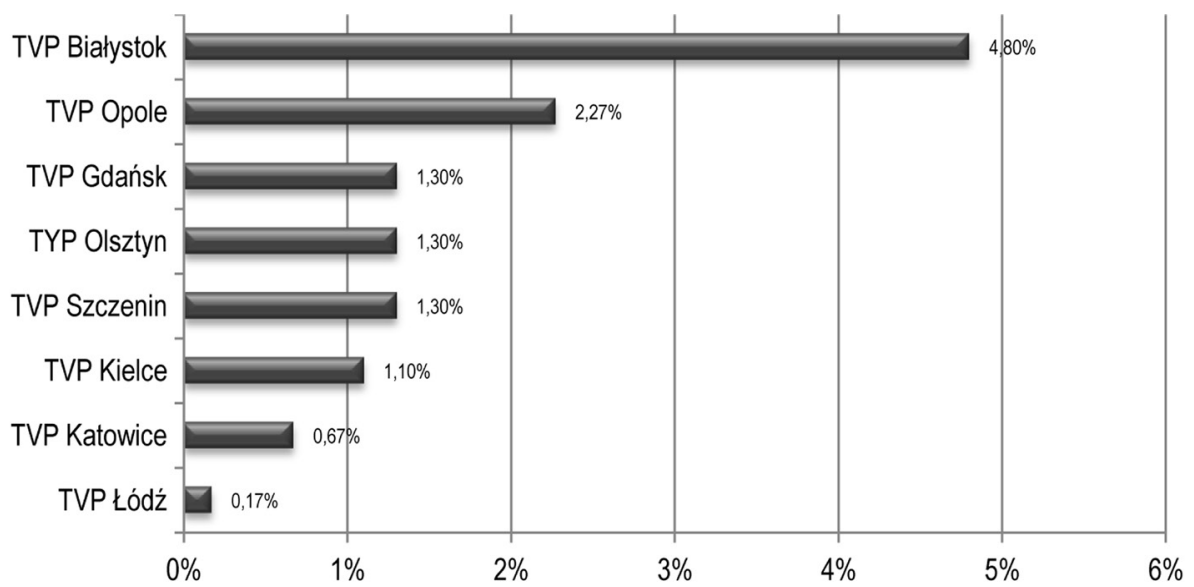

Figure 4. The share of broadcasts for national and ethnic minorities and broadcasts in regional languages in regional branches of TVP S.A.

Source: the author's elaboration on the basis of the data contained in KRRiT, Media Publiczne 2012..., op. cit.

In the case of TVP S.A., funds from subscriptions allocated for its activity represent less than $19 \%$ of its total budget, and a total cost of its annual and undistorted work is 1,75 billion $\mathrm{PLN}^{13}$. In 2012 the public television received nearly 236,5 million PLN from subscriptions, and in the same

12 KRRiT, Media Publiczne 2012..., op. cit., p. 22.

${ }^{13}$ KRRiT, Informacja o podstawowych..., op. cit., p. 77. 
year costs of its missionary activity 'were covered from subscriptions in $18 \%$, from other public revenues in $2 \%$ (e.g. budget subsidies) and in $80 \%$ from the company's own revenue (mainly from sale of advertising time) ${ }^{14}$. Costs related to creation and transmission of broadcasts for minorities in local branches in 2012 reached 1118 thous. PLN in total.

\section{CONCLUSIONS}

Polish legal considerations allow national and ethnic minorities to realize and broadcast their own radio and television programs. Their main carriers are regional branches of public media which, while broadcasting for minorities, implement the so-called missionary activity. At the same time it should be noted that the right to broadcast is guaranteed only to those minorities who fulfill the conditions set out in the Act of $6^{\text {th }}$ Jan. 2005 r. on National and Ethnic Minorities and Regional Language.

The factors which in the current legal situation definitely determine the creation and broadcasting of the programs for minorities seem to be financial issues and initiative and activity of minorities themselves. Programs broadcast by public media are in vast majority financed with subscriptions and broadcasters' own revenues. However, those funds are largely limited by such factors as low subscription chargeability and as in the case of regional stations, relatively small income from the sale of the air time. Part of the broadcasts have other sources of funding. However, they are individual cases associated with individual actions taken by particular minority communities.

Despite difficult financial situation of public media it can be seen that in the case of regional branches of the Polish TV in the years 2008-2011, in most of them there was a steady increase in broadcasting time of programs for minorities (from 179.6 hours in 2008 to 270.4 hours in the year 2011). The exception in this respect was the television in Gdańsk, where there was a significant decrease in broadcasting time from 37.6 hours in 2008 to 23.5 hours in 2011. On the other hand, the leader was undoubtedly the local branch in Białystok, which issued 37 hours of broadcasts in 2008, and in $2011-71.9$ hours.

Also in the case of regional radio stations the increase in broadcasting time of programs for minorities could be observed during the period. However, the combined statements of data from all the regional stations clearly show that there was a sharp decline in the broadcasting time of the programs from 1948.3 hours in the year 2008 to 927 hours in 2011. The difference was

${ }^{14}$ KRRiT, Media Publiczne 2012..., op. cit., p. 30. 
due to the cessation of broadcasting for minorities by the station Warszawa Radio dla Ciebie S.A., which in 2008 broadcast a total of up to 1112 hours.

The other factor, which is the initiative and activity of minorities, is particularly important not only for initiating broadcasting, but also for realization of the broadcasts, which was clearly indicated by KRRiT in criteria saying about properly prepared broadcasts. It primarily depends on the people who prepare a particular broadcast which topic is chosen and how it is covered, and hence, whether the broadcaster gains their stable audience and may hope for continuity of broadcasting.

\section{BIBLIOGRAPHY}

Giedrojć M., Problem środków masowego przekazu oraz dostępu do nich mniejszości narodowych i etnicznych w pracach Komisji Mniejszości Narodowych i Etnicznych Sej$m u R P$, the paper presented during the III International Scientific Conference on the topic 'National and ethnic minorities in Poland on the European background. Media of minorities, minorities in media', which was held in Lublin on 11-13 June 2013.

GUS, Przynależność narodowo-etniczna ludności - wyniki spisu ludności i mieszkań 2011, http://www.stat.gov.pl/cps/rde/xbcr/gus/Przynaleznosc_narodowoetniczna_w_2011_NSP.pdf (30.05.2013).

KRRiT, Informacja o podstawowych problemach radiofonii i telewizji w 2012 roku, http:// www.krrit.gov.pl/Data/Files/_public/Portals/0/sprawozdania/spr2013/informacja_ krrit_2013.pdf (30.05.2013).

KRRiT, Media Publiczne 2012. Aneks do sprawozdania, http://www.krrit.gov.pl/Data/ Files/_public/Portals/0/sprawozdania/spr2013/aneks_2013.pdf (30.05.2013).

KRRiT, Realizacja misji mediów publicznych w zakresie nadawania audycji dla Mniejszości narodowych $i$ etnicznych oraz spoteczności postugujaccej sie językiem regionalnym, http://www.krrit.gov.pl/Data/Files/_public/Portals/0/konferencje/mniejszosci_maj_2012/prezentacja_spotkanie_31-05-2012.pdf (30.05.2013).

KRRiT, Stanowisko Krajowej Rady Radiofonii i Telewizji w sprawie audycji dla mniejszości narodowych i etnicznych oraz spoteczności postugujacej sie językiem polskim w publicznej radiofonii i telewizji, http://www.krrit.gov.pl/Data/Files/_public/Portals/0/stanowiska/st2010/st_101027_mniejszosci.pdf (30.05.2013).

PAP, Rośnie ściagalność abonamentu. Zastuga Poczty?, http://www.polskieradio.p1/5/3/ Artykul/751958,Rosnie-sciagalnosc-abonamentu-Zasluga-Poczty (30.05.2013).

Ustawa z dnia 29 grudnia 1992 r. o radiofonii i telewizji z pózniejszymi zmianami, Dz.U. 1993, nr 7, poz. 34, Dz.U. 1995, nr 66, poz. 335 i Dz.U. 1995, nr 142, poz. 701 , art. 22 ust. 2 , art. 23 ust. 1.

Ustawa z dnia 6 stycznia 2005 r. o mniejszościach narodowych i etnicznych oraz o jezzyku regionalnym, Dz.U. z 2005 r. nr 17, poz. 141, nr 62, poz. 550, z 2009 r. nr 31, poz. 206, nr 157, poz. 1241. 
